\title{
La imagen de Granada en la poesía española del Barroco
}

\author{
Andrés SÁNCHEZ MARTÍNEZ \\ Departamento de Literatura Española \\ Universidad de Granada \\ andressanchez605@gmail.com
}

Recibido: $14 / 09 / 2014$

Modificado: $11 / 11 / 2014$

Aceptado: 05/12/2014

\section{Resumen}

El discurso literario de Granada presenta diversas imágenes que se van modificando a lo largo de la historia y en función del tratamiento de los diferentes autores. Este trabajo se centra en las imágenes poéticas que se dan en el Barroco español, principalmente en autores como Luis de Góngora, Agustín de Rojas, Pedro Soto de Rojas, Lope de Vega o Calderón de la Barca. Las imágenes que estos poetas van construyendo nacen en la Edad Media y dejan huellas hasta el siglo XX. Se busca así analizar la lectura y construcción literaria que los poetas barrocos han hecho de la ciudad y la modificación o eliminación de esos tópicos literarios con el paso del tiempo.

Palabras clave: ciudad poética, Granada, imagen, jardín, paraíso.

Title: The poetic image of Granada in the Spanish baroque poetry

\section{Abstract}

Granada's literary discourse presents images that change over time and under the perspectives of different authors. This research will focus on the poetic images that occur in the Spanish Baroque, particularly in authors like Luis de Góngora, Agustín de Rojas, Pedro Soto de Rojas, Lope de Vega or Calderón de la Barca. The imagery that these poets create born in the Middle Ages and continue in the twentieth century. The purpose is to analyze the reading and literary construction that baroque poets have made of the city as well as the modification or removal of these literary topics over time.

Keywords: poetic city, Granada, image, garden, paradise.

\section{Índice}

1. Introducción

2. Descripción de la ciudad

3. Imágenes de Granada en el Barroco

4. Algunas continuaciones en los siglos XIX y XX a las imágenes de Granada

5. Conclusión 


\section{Introducción}

La ciudad ha sido desde antiguo fruto de constante interés en tanto que foco en el que se concentra la mayor parte de la población y de las relaciones sociales y comerciales. En el caso de Granada, este hecho goza de un relieve especial debido a su historia: cuna del esplendor artístico y de prosperidad económica y política como Reino Nazarí hasta la conquista por parte de los Reyes Católicos en 1492, convirtiéndose en uno de los centros del Imperio. Este trabajo se podría limitar al estudio de Granada desde una perspectiva puramente histórica o urbanística; sin embargo, en este caso, me centraré en el estudio de la ciudad literaria o, por decirlo de otra manera, en la imagen (o imágenes) de Granada que la poesía española ha ido construyendo a lo largo del tiempo. Se introducirán las tres imágenes literarias de Granada: ideal, casticista o críticotrágica, tomando como centro la primera y los cambios que se producen en diferentes autores. Al mismo tiempo, se hará un recorrido cronológico que se detendrá principalmente en el Barroco, uno de los períodos en donde más se ha poetizado Granada, para acabar en las modificaciones de los siglos XIX y XX. Se partirá, como método de análisis, de una consideración de la ciudad no como simple telón de fondo en el poema sino como discurso en sí misma.

Esta perspectiva de estudio pondrá a la ciudad como centro, es decir, como texto y discurso construido por los poetas que van creando la imagen, y por los lectores de la misma, que la van interpretando. La ciudad así entendida es, en definitiva, un "signo" (Fraticelli 2006). Por ello, un estudio satisfactorio del espacio urbano así entendido debe llevar a cabo un análisis semiótico de su estructura y funcionamiento como texto. En Semiología y urbanismo, Roland Barthes explica los pasos del análisis a seguir: "[...] disociar el texto urbano en unidades; luego, en distribuir esas unidades en clases formales, $y$, en tercer lugar, en encontrar las reglas de combinación y transformación de estas unidades y esos modelos" (Barthes 2009: 343). En este caso se buscarán las "piezas" de la "microestructura" de la ciudad, como pueden ser la Alhambra o los cármenes -las "unidades" del texto urbano-, para después llegar a la "macroestructura", es decir, al funcionamiento de la ciudad en general o de cada una de sus partes: la ciudad musulmana y la ciudad renacentista. En última instancia, para buscar las reglas de funcionamiento y transformación de las unidades semióticas de la ciudad -Alhambra, jardines, cármenes- y su interacción con la macroestructura, se analizará la contribución de cada poeta al discurso urbano.

Las imágenes poéticas de Granada se rastrean desde la literatura árabe, entremezclada en muchas ocasiones con la arquitectura. En esta poesía se encuentran ya algunas imágenes de la ciudad que llegarán -con modificaciones- al siglo XX. Sobre todo, la 
imagen que está surgiendo es la del paraíso terrenal, y es lógico, pues es éste el objetivo que se persigue con la construcción de la Alhambra. Para conseguirlo, no sólo se valdrán de arquitectos y jardineros sino también de poetas, que cultivarán esta imagen paradisíaca de la ciudad, ya desde el siglo XI, con poetas como Ibn Sara:

Los ojos de los hombres se vuelven hacia Granada, pues ella es el jardín que despliega sus flores como las de un manto estriado.

Tras las nubes nocturnas, cuyas lágrimas, pequeñas y gruesas, parecen perlas, cometeréis locuras en esas corrientes de agua que recuerdan al pecho de una hermosa mujer [...]. (Ibn Sara apud Salvador 1996: 23-24)

Junto a esta poesía, comienzan a emerger romances en castellano que después serán renovados por poetas como Luis de Góngora (1561-1627), autor de uno dedicado a Granada. De esta forma, son los romances fronterizos el inicio del discurso poético (en castellano) de esta ciudad. Una de las primeras imágenes poéticas de Granada aparece en el romance de Abenámar, que Menéndez Pidal fechaba en 1431.

Este romance fronterizo desarrolla uno de los tópicos literarios de la época: la imagen de la ciudad como mujer esquiva que es cortejada por el rey, prendado por su belleza. Encontramos aquí una de las primeras descripciones poéticas de la ciudad, resaltándose el esplendor de algunos de sus edificios, entre los que destaca la Alhambra, cuya fastuosidad el poeta describe al hablar de las riquezas que ganaba el moro escultor. Granada es aquí un objeto de deseo que se explica en el contexto de la reconquista por parte del cristianismo de las plazas que querían anexionarse en la lucha contra el Islam. La necesidad de conquista, las ansias de poder y de legitimación de la ideología religiosa del Imperio explican el surgimiento de la imagen de Granada como mujer deseada.

En el Barroco surgirán otros poemas descriptivos y laudatorios, como el extensísimo poema Granada de Agustín Collado del Hierro o el complejo Paraíso cerrado para muchos, de Pedro Soto de Rojas, que explotan la imagen de la ciudad como paraíso terrenal, llegando a la construcción de un tópico literario.

Este trabajo dará un salto después del Barroco para terminar en los siglos XIX y XX. El impulso de los viajeros románticos dará a conocer una nueva imagen de la ciudad, a menudo falseada, que será recogida por los poetas españoles, sobre todo por José Zorrilla (18171893), para llegar al Modernismo y pasar el testigo a Francisco Villaespesa (1877-1936). En el siglo XX se seguirán aportando 
modificaciones a la visión de Granada, sobre todo por parte de la poesía de Juan Ramón Jiménez (1881-1958) y de Federico García Lorca (1898-1936). Queda así esbozado el itinerario que este trabajo pretende seguir, una vez fijado el centro en la poesía barroca. Se verá así el abigarrado mosaico de las diferentes aportaciones poéticas a Granada, que forman varias imágenes de la ciudad. Esto nos ayudará, después de haber delimitado la estructura urbana, a ver el funcionamiento que las diferentes lecturas e imágenes literarias tienen en el espacio urbano.

\section{Descripción de la ciudad ${ }^{1}$}

Antes de entrar en la poesía hagamos un breve itinerario desde el punto de vista urbanístico. La primera mención la merece el enclave especial que elige la ciudad islámica: una zona escarpada de difícil acceso, cerca de un curso de agua (Montero Vallejo 1996: 110-113). Frente a los enclaves romanos que preferían planicies que facilitaran los desplazamientos y el comercio, las ciudades islámicas privilegian su seguridad, pues la defensa ante los asaltos cristianos es lo único que puede dar prosperidad al reino, tanto política como económica. El Qirtās señala los cinco factores imprescindibles en una ciudad: "agua corriente; tierras fértiles a su alrededor; un bosque próximo que le suministre leña; unas sólidas murallas; un jefe fuerte que sepa mantener el orden" (1996: 131). Estos condicionantes podrían valer para cualquier ciudad, pero en el caso de Granada cobran una relevancia especial. Primero, el culto al agua, tanto en las zonas de recreo como en las tierras de cultivo; y los espacios fértiles que permitan el autoabastecimiento de una ciudad que busca ser inexpugnable.

La ciudad islámica se va perfilando así con dos caras indivisibles: la civil (Medina) y la parte militar (Alcazaba), añadiéndose un tercer sector, los arrabales. En la medina se disponía el zoco, centro comercial como era el barrio de la Alcaicería en Granada y también el centro religioso de la mezquita. Pero en Granada se encuentran a su vez dos ciudades diferentes, la medieval o musulmana y la renacentista, que se entremezclan y conviven de forma sincrética en algunos puntos. Uno de los más conocidos es el Palacio de Carlos V, construido en el corazón de los Palacios Nazaríes,

${ }^{1}$ La fundación de la ciudad propiamente dicha proviene de los primeros años del siglo XI, durante el reinado de la dinastía zirí. Como consecuencia de las luchas internas, la ciudad de Elvira (Iliber, Iliberri, Iliberis) queda destruida y su población árabe pasa a la poco poblada Granata, que había sido anteriormente un pequeño enclave romano y visigodo. Muy interesante es el testimonio de Abd Allah (el último rey zirí) sobre la traslación a Granada (cfr. Villa-Real 1990: 30). Sobre todos los detalles urbanísticos e históricos, tanto en el texto como en la bibliografía que incluye, véase la obra de Montero Vallejo (1996). 
para lo que fue necesario derribar varias salas de la Alhambra. La ciudad árabe aún conserva alguna de las puertas de entrada anexas a la muralla. Una de ellas es la Puerta de Elvira, por la que se entra a la calle del mismo nombre, centro neurálgico de la ciudad musulmana y entrada al barrio del Albaicín. Salpicado en su irregular trazado de calles medievales, hay un gran número de miradores -como los de San Nicolás, San Cristóbal o el de la Cuesta de los Chinos- que dejan al descubierto una de las facetas más importantes de la ciudad: Granada está hecha no para producir o comerciar (imposible en el desorden de calles del Albaicín) sino para mirarla y admirarla. Es una ciudad que se construye como réplica del paraíso.

La Alhambra y el Generalife se construyen para el deleite de los sentidos y a este cometido se unen muchas artes y oficios -la arquitectura, la escultura, la poesía o la jardinería-, para reproducir el paraíso. Esto es lo que se busca en el Patio de los Leones:

Estamos ante otra de las tipologías [...] del modelo jardín-paraíso de la tradición irania. [...] formado por dos canales perpendiculares que dividen el patio en cuatro partes, representaciones simbólicas de las cuatro partes del mundo. En el lugar donde los dos canales se cortan, se situaba una roca, una columna, un pabellón o una fuente de la que brota el agua, simbolizando la Montaña Cósmica en donde se unen la tierra y el cielo que es también el centro del universo y la fuente de la vida. [...] en la más ortodoxa tradición árabe, el jardín estaba rodeado de altos muros para protegerlo de las miradas y de los peligros del exterior. (Salvador 1996: 60-62)

He aquí la descripción de uno de los paraísos de la Alhambra, que se llevará a la literatura. Se busca que el goce en este locus amoenus sea total y que, a través de él, se pueda llegar al éxtasis, pues todos los sentidos participan -la vista ve la belleza arquitectónica y escultórica al mismo tiempo que los jardines y los reflejos de la luz en el agua; el oído percibe el lenguaje de las fuentes, el gusto probaría las frutas y el tacto los numerosos relieves. Al mismo tiempo, la temperatura se torna perfecta al unir el sol de esta zona geográfica con la sombra de los árboles y el frescor de las fuentes. Tenemos aquí la unión entre naturaleza y arquitectura que se prolonga a la zona privada del individuo en el carmen, la casa típica de la ciudad musulmana. Está conformada, además de por la zona de vivienda, por un jardín y una huerta con su correspondiente fuente, todo ello rodeado de altos muros que aíslan el recinto del exterior, el perfecto paraíso árabe alejado del ruido mundano.

La ciudad renacentista es diferente, las calles son más anchas y despejadas, como sus edificios, la catedral y el palacio de la Real Chancillería. Granada se sigue transformando y se vuelve hacia lo abigarrado en la arquitectura. Pero la máxima transformación de la ciudad vendrá después. 
Desde la Revolución Francesa y la aparición de la República, en cambio, la ciudad moderna, lugar donde vive la nueva clase emergente, la burguesía, empieza a desarrollarse alrededor de un espacio profano, relegando a un papel marginal el espacio de la Catedral. [...] La función defensiva de las murallas [...] deja de tener importancia estratégica; empiezan a poblarse zonas impensables hace unos siglos, los arrabales, que se distinguen enseguida de las zonas intra-muros. De esta forma, una nueva clase social entra prepotentemente a formar parte del paisaje urbano, los proletarios [...]. Llega la iluminación a las calles, se plantan árboles en los bulevares y se crean parques para uso y disfrute de los habitantes de la ciudad, lo cual modifica la fisonomía urbana de una forma importante. (Fraticelli 2006: 8-9)

Granada también experimentará los cambios que sufre la ciudad moderna. Hay que destacar en este particular la inauguración de la estación de ferrocarril en la segunda mitad del siglo XIX, que propicia un mayor tráfico de personas. Para facilitar el movimiento y la comunicación rápida por la ciudad se diseña la Gran Vía, siguiendo el modelo de la Avenida de la Ópera de París, inaugurándose en 1892. La construcción de esta gran avenida supuso la ruptura de gran parte del trazado medieval que aún se conservaba, mediante una gran operación de derribos. Se llega de esta forma a un tipo de ciudad utilitaria, contraria a los orígenes de la ciudad de recreo que fundaron los árabes. El Barroco literario ahondará en esa imagen de la ciudad como paraíso, cima de esplendor político y artístico. A partir del siglo XIX y por oposición a su realidad industrial, se continuará con esa imagen poética de la que la ciudad real se alejaba.

\section{Imágenes de Granada en el Barroco}

En la literatura de finales del siglo XVI y del siglo XVII se poetizó masivamente la ciudad de Granada, tanto la parte árabe como la renacentista. Muchas de las imágenes que se desarrollarán en esta época proseguirán en el Romanticismo, momento de máximo apogeo y popularización de Granada en la literatura universal. Pero descontando el siglo XIX, será en la época barroca cuando más aportaciones se hagan al discurso literario de Granada; prácticamente todos los autores que gozaban de renombre habían visitado y poetizado la ciudad andaluza. En esta ocasión limitaré el análisis a los textos de Luis de Góngora, Agustín de Rojas (1572-1635) y Pedro Soto de Rojas (1584-1658), junto con alguna otra mención. El tono de esta poesía suele ser altamente laudatorio, alabando las grandezas y la belleza que los poetas ven en la ciudad. Pero este tono curiosamente alternará con la crítica y la sátira de autores como Cervantes. Inicialmente, como veremos en los ejemplos concretos, se prosigue con la imagen de Granada como paraíso que procedía de los 
romances fronterizos y que los reyes nazaríes habían querido construir en sus palacios. Al mismo tiempo, circulaban escritos que favorecían un mayor conocimiento de la ciudad.

Las principales obras de referencia de la época, que sirvieron de inspiración en muchas ocasiones, fueron principalmente tres (Orozco Díaz 2000): las Guerras civiles de Granada (1595) de Pérez de Hita; la Historia de la rebelión de los Moriscos (1600) de Luis del Mármol y la de Francisco Bermúdez de Pedraza, Antigüedades y Excelencias de Granada (1608). Pero mucho antes que todas ellas se popularizó un romance de Góngora que veremos a continuación. Ahora bien, ¿qué causa tanto interés por Granada? La explicación es lógica: si ya veíamos en el romance de Abenámar el deseo de conquista del último enclave musulmán en la península para los intereses imperiales, ahora se trataba de exaltar la magnificencia de esa ciudad que había significado y significaba todavía tanto en la mentalidad contrarreformista. Había llegado el momento de elevar a la categoría de ideal literario una ciudad que simbolizaba el poderío imperial frente a lo pagano. Una vez que la conquista estaba más que asentada, se podía alabar la belleza de Granada y el ideal caballeresco que representaba lo árabe. De esta forma, se estaba exaltando un pasado heroico que legitimaba a la monarquía.

El gusto de la literatura barroca por Granada se popularizó en gran medida por el romance de Góngora, escrito en 1586 y que empezaría a generalizar la imagen de Granada como paraíso. La composición es una amplia descripción de la ciudad que ocupa más de doscientos versos, que ya contiene algo de la forma descriptiva gongorina tan sensorial que culminará en las Soledades. El romance está constituido por tres partes que se pueden establecer en virtud del espacio descrito. Pero antes coloca una breve introducción que sitúa la ciudad (Góngora 2000: vv. 1-16). La primera parte (vv. 17148) realiza un inventario de los principales monumentos de la ciudad; la segunda ( $v v .149-192$ ) se centra en la naturaleza y la tercera (vv. 193-236), en los habitantes de la ciudad, pero únicamente del sexo femenino. He aquí una manera de estructurar el poema, aunque todo forma un conjunto unitario: así, los elementos naturales se entremezclan con las calles y palacios de la Alhambra -y se introducen en el carmen, en el ámbito doméstico. Al mismo tiempo, las mujeres granadinas a las que alaba Góngora son inseparables de la ciudad, que no sería tan bella si no las tuviese, y ellas no gozarían de sus encantos si estuviesen en otro lugar. Así, el espacio urbano está compuesto por unidades inseparables: monumentos, naturaleza y mujeres.

El sujeto poético confiesa la razón por la que está en Granada. Ha ido a ver la ciudad y esta expresión se convierte en un elemento clave en el poema. "De mi patria me trujiste, / no a dar memorïales / de mi pleito a tus oidores, / de mi culpa a tus alcaldes; / sino a ver 
de tus murallas / los soberbios homenajes, / tan altos, que casi quieren / hurtalle el oficio a Atlante [...]" (Góngora 2000: vv. 13-20). Desde el punto de vista estructural, la expresión a ver da entrada a una parte de la ciudad que la voz poética ha ido a visitar y que describe a continuación, marcándose la transición cuando la mirada pasa a de un espacio a otro. En este caso, ha descrito las altas murallas y pasará después a la Alhambra, que se encadena con la imagen anterior mediante esta expresión. De esta forma, se separan los diferentes elementos urbanos. Pero a ver también marca la intencionalidad pictórica del poema, cuyos elementos deben alcanzar tal materialidad que puedan verse. Gracias a esta estructuración (aunque parezca contradictorio), el poema se mueve con gran naturalidad de un espacio a otro, de la parte al todo de un edificio. Casi se podría indicar que la expresión a ver sería, más que un ojo, una cámara que comienza haciendo una panorámica de la ciudad para detenerse en los diferentes edificios y seleccionar después lo que le interesa de ellos, y lo mismo hace con la naturaleza y las mujeres.

La poética de Góngora se sirve, mediante esta forma en la que el sujeto poético mueve el objetivo, de una técnica casi cinematográfica que consigue ser muy fructífera para su intención: la descripción y alabanza de Granada². Sigamos descomponiendo la aportación de Góngora al discurso de la ciudad:

\author{
Ilustre ciudad famosa \\ infiel a un tiempo, madre \\ de Cegríes y Gomeles, \\ de Muzas y Redüanes, \\ $[\ldots]$ \\ Ciudad (a pesar del tiempo) \\ tan populosa y tan grande, \\ que de tus rüinas solas \\ se honraran otras ciudades (vv. 1-12)
}

El romance comienza con alabanzas, destacando el pasado heroico en las figuras arquetípicas de musulmanes distinguidos, para situar después la ciudad a vista de pájaro. Así, el objetivo mira desde lo más alto y ve a la ciudad entre los dos ríos (Darro y Genil), pero a medida que se aproxima ve más: ruinas. Este será uno de los tópicos barrocos más manidos, el período nazarí queda lejos y los edificios se van deteriorando. A pesar de todo, el tono laudatorio vence: esas ruinas sobrepasarían a cualquier otra ciudad. Con la repetición de la

2 Un año después dedicará un soneto a Córdoba: "si entre aquellas rüinas y despojos / que enriquece Genil y Dauro baña / tu memoria no fue alimento mío, // nunca merezcan mis ausentes ojos / ver tu muro, tus torres y tu río, / tu llano y tu sierra, ioh patria, oh flor de España!" (Góngora 1992: 54, vv. 9-14). 
estructura a ver, el plano se va reduciendo cada vez más: de la primera panorámica se pasa a las murallas, que se traspasan, y se llega al interior de la Alhambra, más concretamente al Patio de los Leones y a la sala de Comares.

El recorrido no se detiene ahí, el sujeto poético quiere ir a los espacios más secretos de palacio. Se describen así los lugares a los que nadie tiene acceso, la zona más privada: el baño de la reina. "[...] y a ver sus secretos baños, / do las aguas se reparten / a las sostenidas pilas / de alabastro en pedestales, / do con sus damas la reina / bañándose algunas tardes, / competían en blancura / las espumas con sus carnes" (vv. 45-52). El sujeto poético se recrea en esta imagen cargada de erotismo y, al mismo tiempo, de vida. No describe los monumentos sin más, sino la belleza viva y más carnal que habita en su interior: la reina. Se pasa después a ver la ciudad renacentista: la Chancillería, la catedral, la Capilla Real, la universidad y el Monasterio de San Jerónimo. Ha recorrido los centros religiosos, civiles y educativos de la ciudad, y finaliza la primera parte del romance: "[...] y a ver tu Albaicín, castigo / de rebeldes voluntades, / cuerpo vivo en otro tiempo, / ya lastimoso cadáver $[\ldots]^{3 \prime \prime}$ (vv. 145-148). Aquí aparece la imagen de la ciudad como cuerpo. Pero el Barroco hace que este cuerpo, que antaño florecía de esplendor y vida, ahora esté muerto, en ruinas. En este fragmento aparece una de las mayores obsesiones del poema y que se expresará al final: el combate contra el tiempo. El poeta ve el inexorable paso del tiempo, que reduce a ruinas las bellezas de la ciudad, y contra eso pretende luchar en el romance.

El sujeto poético pasa a describir ahora la naturaleza: la Vega y el Generalife. Su imagen de esta zona es una de las más populares, que partía desde la literatura árabe y que llegará hasta el siglo XX. Se está desarrollando la imagen de la ciudad-paraíso:

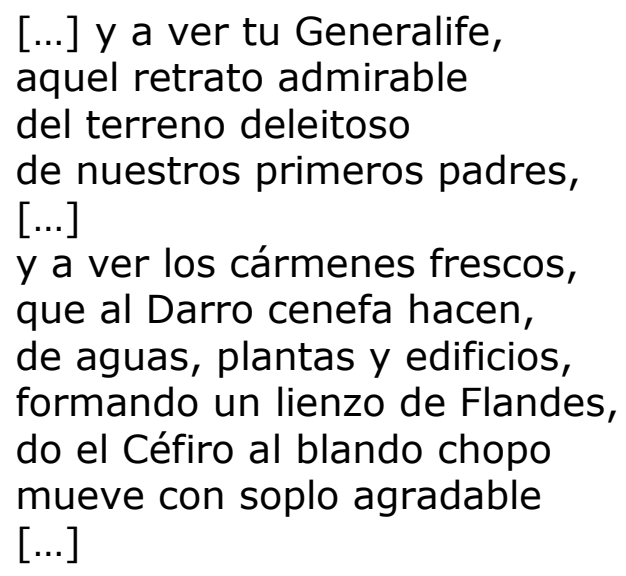

3 Se refiere a la soledad del Albaicín, después de la expulsión de su población. Véase la nota 145 de la edición de Antonio Carreira (Góngora 1998: 385). 
y del verde Dinadámar

a ver los manantiales

a quien las plantas cobijan

porque los troncos les bañen,

entre cuyos verdes ramos

juntas las diversas aves,

a cuatro y a cinco voces

cantan motetes süaves; [...]. (vv. 153-184)

Queda así constituida con gran delicadeza la imagen del locus amoenus. Para ello, se vale de elementos naturales (plantas, agua) y del canto de los pájaros, que hacen del lugar un verdadero paraíso. Después, unirá a esta naturaleza "salvaje" la naturaleza domesticada, los jardines del Generalife: "aquel retrato admirable / del terreno deleitoso / de nuestros primeros padres". Pero esta imagen paradisíaca no sólo reside en la naturaleza, está en toda la ciudad que, a su vez, también es naturaleza. Góngora lo deja muy claro, por encima de cada monumento o fuente particular, Granada es "aguas, plantas y edificios" (v. 167). Es decir, arquitectura y naturaleza perfectamente unidas de tal manera que, a vista de pájaro, la ciudad parece un "lienzo de Flandes" (v. 168). Este encadenamiento de imágenes da testimonio de una ciudad que vive en comunicación con la naturaleza, no sólo en los jardines palaciegos sino también en la propia casa. En el ámbito más privado del carmen se vive en contacto con el agua de la acequia, y con el jardín o huerto.

Góngora termina su descripción de Granada con lo que, en su opinión y en un tono de evidente galantería, más belleza le aporta a la ciudad: las mujeres. Como en la escena del baño de la reina, en la poesía gongorina la vida -lo sensual, lo femenino e incluso la vida natural- se suele imponer a las bellezas arquitectónicas. El sujeto poético termina con la imagen de la belleza femenina la descripción de todo lo que ha venido a ver a Granada, todos los elementos que embellecen a la ciudad y que conforman su imagen poética.

En tu seno ya me tienes, con un deseo insaciable, de que alimenten mis ojos tus muchas curiosidades, dignas de que por gozallas, no sólo se desamparen las comarcas del Betis, mas las riberas del Ganges, [...] 


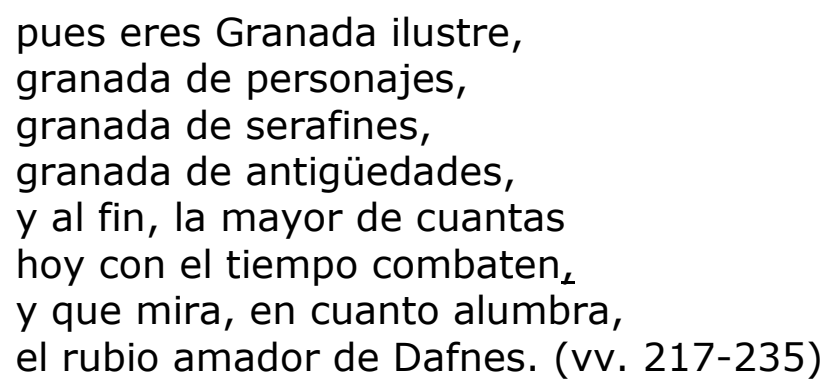

Desarrolla así la "finalidad" de ir a la ciudad-paraíso, que no puede ser otra que gozar, aunque sea de forma preeminentemente visual. El sujeto poético ha venido, sobre todas las cosas, a ver y ahora quiere saciar su deseo de belleza con la visión de todos los elementos de la ciudad que ha ido describiendo. Góngora finaliza resumiendo los tres elementos principales de los que se compone el espacio urbano -héroes, bellezas femeninas y naturales, junto con los monumentos-, mediante el juego entre el nombre de la ciudad como sustantivo y como verbo: Granada/granada. Después, el tono cambia. Las bellezas "hoy con el tiempo combaten". Esta es la problemática de la imagen gongorina de Granada como paraíso irrealizable en la práctica. Es una ciudad que lucha contra el paso del tiempo, que ha conseguido reducir a ruinas a algunos de sus puntos (el Albaicín, la Alhambra y otros puntos que "purgaba" el río al inicio del romance). De esta forma, el poema se conforma como alegato contra el paso del tiempo. Puesto que Granada no puede ser un paraíso real, lo será en su poema, el único espacio atemporal.

La segunda imagen poética que sería interesante destacar es la que ofrece Agustín de Rojas en su Viaje entretenido (1603), al que le dedico un espacio en este trabajo por dos motivos. En primer lugar, por ser la prueba de la gran popularidad de la imagen de la ciudad que Góngora generó con su romance. En segundo lugar, por encuadrarse esta imagen en el género concreto de la loa, que a su vez la hizo aún más famosa, hasta convertir el elogio de Granada en un tópico literario. Esta popularización masiva viene determinada por el género mismo: la loa se intercalaba en las representaciones dramáticas, recitadas por un poeta o por un actor que invitaba a los espectadores a que tuvieran cierta clemencia con los errores que se pudieran cometer en la representación. Era una forma, en resumidas cuentas, de ganarse el favor del público desde antes de empezar a actuar. Por el hecho de intercalarse en la obra, llegaba a un público mayor que un poema normal y corriente, por lo que facilitó una mayor difusión de la imagen laudatoria de Granada. Pero al mismo tiempo no nos salimos del molde del romance en el que esta loa de elogio está compuesta.

La loa se introduce en el libro II del Viaje entretenido, precedida por una conversación entre los comediantes Ríos, Ramírez, 
Solano y Rojas, donde comentan las bellezas de Granada. Primero hacen un recorrido por la Alhambra exactamente por los mismos sitios por los que pasó el romance de Góngora: sala de los Abencerrajes ( $y$ al igual que en el romance, se alude a la leyenda de que en la fuente quedan rastros de la sangre de los caballeros que allí fueron degollados), sala de las Frutas, sala de Comares, Alcazaba, Generalife y los ríos, de los que se dice -otra imagen muy recurrente, que se rastrea también en Góngora ${ }^{4}$ y recogerán los románticos ${ }^{5}-$ que el Genil lleva plata y el Darro, oro. La loa parte de un tópico barroco: la tempestad que se desata en el mar y los náufragos recibidos con hospitalidad en tierra, en este caso en la costa granadina. Por ello, se procede al elogio: "iOh, mil veces venturosa / ciudad que a todos amparas, / y en tu milagroso puerto / los afligidos descansan!" (Rojas 1972: 188). Posteriormente se inicia una enumeración acumulativa de sustantivos verdaderamente desmesurada. Como hace notar el profesor Orozco Díaz (2000: 50), este debía ser un recurso muy del gusto del público gracias a una recitación efectista.

La situación del naufragio y de la hospitalidad de los lugareños es seguida por el elogio de la ciudad. Y, como se ha dicho, se recurre a la repetición encadenada de sus atributos, situándola primero y recontando sus virtudes como la más importante del mundo después. Todos los ámbitos del ser humano aparecen en Granada: la fuerza, la sabiduría, el valor, la riqueza. Pero la enumeración acaba de empezar, y así sigue alabando hiperbólicamente la ciudad:

Tú relumbras entre todas,

cual suele el fuego o luz clara,

en medio de las tinieblas,

a quien el bello sol falta.

Tú, señoril, elocuente, gloriosa, prudente, sabia, populosa, antigua, fuerte, altiva, cortés, hidalga, dichosa, soberbia, rica, $[\ldots]$

\footnotetext{
${ }^{4}$ En un soneto que dedica a Pedro Soto de Rojas, fechado en 1612: "Sus corrientes por él cada cual trata, / las escuche el Antípoda remoto, / y el culto seno de sus minas roto / oro al Dauro le preste, al Genil plata. [....]" (Góngora 1992: 88, vv. 58).

${ }^{5}$ Como Chateaubriand, Gautier o el Duque de Rivas (vid. Villa-Real 1990: 112, 118, 122).
} 
Odorífera, oriental,

alegre, admirable, rara,

magnánima, belicosa,

famosa, noble, sagrada,

profetisa, milagrosa,

firme, inexpugnable y alta [...]. (Rojas 1972: 189-190)

Este estilo tan artificioso es, por otra parte, valioso, pues casi podríamos extraer una imagen de la ciudad de cada sustantivo o adjetivo de la enumeración. Prosigue este estilo pero ahora pasa de las virtudes a los edificios y después a zonas concretas (Generalife, Albaicín, Alcazaba, Alcaicería, Zacatín, plaza Bib Rambla, Sacro Monte), comparando de nuevo hiperbólicamente las riquezas de la ciudad con las de Alejandría o Corinto.

Finaliza la loa después de más versos de abigarrada enumeración. No se percibe aquí la delicadeza de las imágenes de Góngora. Sin embargo, esta loa del Viaje entretenido, uno de los mayores éxitos comerciales de la época, ofrece un extensísimo catálogo de todas las imágenes de la ciudad que se explotaban en la poesía barroca, constituyéndose así un tópico literario. Se procede a terminar con las últimas alabanzas: "iOh, insigne ciudad gloriosa! / más te ofende quien te alaba / tu antigüedad te engrandezca, / que mi alabanza no basta" (Rojas 1972: 190-191). Se han visto todas las imágenes de la ciudad que se poetizaban en el Barroco -ciudad gloriosa, odorífera, inexpugnable, antigua, sabia, belicosa. A la vista de este texto se puede apreciar la entidad de personaje que tenía Granada, de la que se puede realizar un análisis en tanto que discurso en sí mismo. En este caso, el discurso es altamente laudatorio y contiene todas las imágenes que ha mostrado Agustín de Rojas, pero presenta variantes. En el caso de Góngora, residen en la construcción de un paraíso que se sabe ficcional y después de la toma de conciencia explícita de ello, surge el interés de perpetuar esta imagen en el poema.

Los testimonios de Góngora y de Agustín de Rojas han ofrecido el abanico de las imágenes que se tenían en el Siglo de Oro sobre Granada, una ciudad ideal, con unos habitantes forjados mediante estereotipos caballerescos, inicio de la maurofilia que se extendería en el Romanticismo. Los versos de Góngora y de Agustín de Rojas han trazado un itinerario por la ciudad, mediante panorámicas o planos más cortos. Acortemos aún más el plano y fijémonos ahora en el ámbito más privado, en el carmen granadino. A este elemento tan concreto del espacio urbano le fue dedicado un extenso poema, el Paraíso cerrado para muchos, jardines abiertos para pocos, de Pedro Soto de Rojas. Después de llevar una vida muy activa entre Granada y la Corte de Madrid, este poeta mandará construirse un carmen en su ciudad natal, que describirá con grandes dosis de erudición. Así, el 
jardín "abierto para pocos" del título alude a varias realidades: a los jardines árabes, al paraíso cristiano y también a su poema, "librojardín" abierto sólo a los más eruditos que sean capaces de interpretarlo. Tal es la dificultad de comprensión del poema, por su excesivo barroquismo y el gran número de referencias teológicas, filosóficas o literarias que contiene, que Francisco de Trillo y Figueroa escribió una explicación del texto.

El jardín de Soto de Rojas no es sólo réplica del árabe, sino que adopta influjos del cristiano medieval y de las villas italianas renacentistas; a esta mezcla se une el sincretismo religioso y cultural. Su jardín no sólo es el paraíso islámico, apto para la contemplación de la belleza. Según afirma Egido (1981: 29), es "una verdadera academia: pasear por él es seguir siempre un itinerario filosófico en busca de la verdad". El poema aparece dividido en siete "mansiones", donde el simbolismo pitagórico del número también está presente, todo ello "sin abandonar la idea de edificar un paraíso terrestre como el que se desprende de las utopías" (Egido 1981: 32). Sin duda, se podría concluir que el poema es "una suerte de peregrinatio por el paraíso terrenal en busca del paraíso celeste, aquel que se presiente -sin alcanzarse- en la mansión séptima" (Egido 1981: 34). Después de limitar en una panorámica el espacio urbano en el que se encuentra el carmen, se inicia la erudita descripción en la Mansión primera: al entrar, una gruta de la que mana el agua de la fuente. Sobre esa cueva, se disponen tres estatuas (vemos ya la mezcla entre naturaleza y, en este caso, escultura) de temática religiosa. Por allí serpentea una acequia a cuyos lados, en el pavimento, hay pinturas, también religiosas; emparrados y cenadores, todo ello decorado con plantas de todo tipo, y la fuente de azulejos.

La Mansión Segunda del carmen se halla subiendo una grada (nótese la estructura en terrazas del carmen y del poema). Allí se encuentran más adornos florales, regados por el agua de otra fuente. De nuevo es necesario subir para llegar a la Mansión Tercera, donde hay árboles frutales y aves que hacen aún más deleitoso el ambiente. En el poema no hay rastro de lo humano, son los pájaros los únicos habitantes "animados" que viven ese espacio: "[...] ramillete de pluma el jilgerillo, / rico galán de la apacible Aurora, / que es flor galante del jardín canora. / Eco suave al dulce paraíso, / camachuelo narciso, / [...] asido al blando ramo, / sube en su voz y se avecina al cielo [...]" (Soto de Rojas 1981: vv. 407-420). Más arriba está la Mansión Cuarta, donde se encuentra un estanque con peces y dos estatuas de jazmín, representando a Neptuno y a Anfitrite. Se baja después a la Mansión Quinta, donde prosigue el recuento de plantas, agua y esculturas mitológicas, y después a la Sexta, donde hay otra fuente y más jardines con esculturas que conectan con la vivienda, cuya descripción se prolonga en la parte Séptima. Queda así sublimada la unión de Naturaleza, escultura y arquitectura. Ahora 
bien, ¿cuál es la pretensión de este espacio?: "[...] perdona mi alabanza, / pues cuando vuela más, menos te alcanza" (vv. 11451146). Se busca alabar al Creador con un espacio lo más bello posible, para llegar al estado de plenitud humana y alcanzar la verdad, o sea, llegar a Dios. El hecho de que esto no sea totalmente posible muestra la imperfección última del ser humano.

Las imágenes de la ciudad no se reducen a la literatura de estos tres autores, veamos algunos más como ejemplo de la inabarcable nómina, y cómo se formulan -aunque de forma breve y poco desarrollada- otras imágenes de Granada en esta época. Después de Góngora, se prosigue con la metáfora de la ciudad como jardín en otros textos como los de Lope de Vega, que llegó a visitar Granada en torno a 1602-1603. Un ejemplo de esta imagen aparece en su comedia El Hidalgo Bencerraje: "Todo es un bello jardín. / Los altos del Albaicín / son fuentes, y por la Vega / que el cristal de Genil riega, / lo es mucho Bibataubín" (apud Orozco Díaz 2000: 63). Como en todos los poetas que se han tratado, se describen las partes de la ciudad y sus monumentos, pero también se dedica espacio al pequeño jardín que se halla en el carmen:

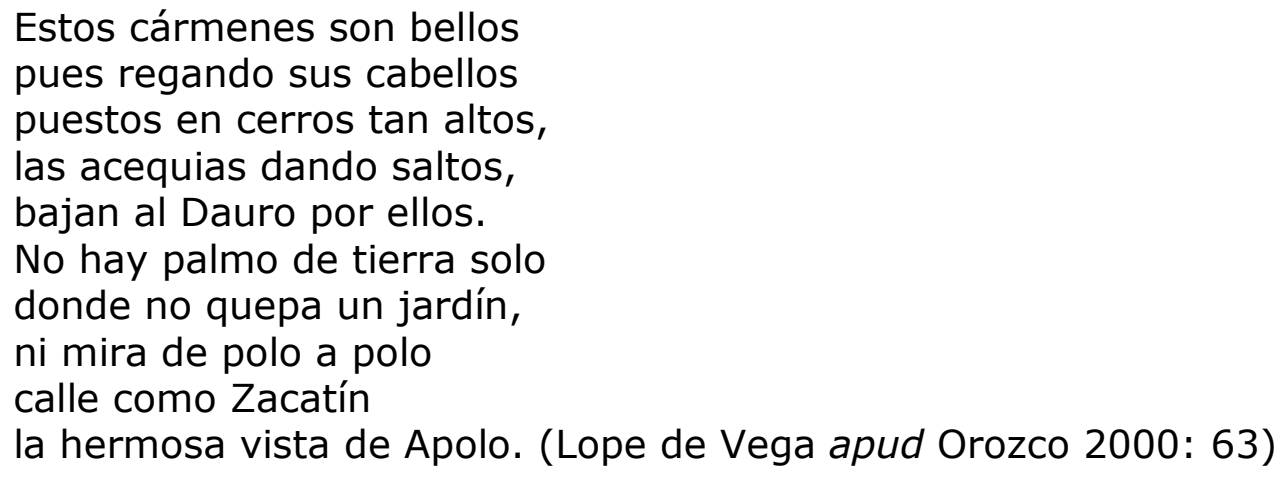

Se ve así la imagen del jardín que entra en la casa y se despliega por toda la ciudad, mezclada con el agua de las fuentes y acequias que riega el espacio urbano. La poética del carmen granadino y de la fertilidad de la ciudad es cultivada también, y de forma muy extensa, en un poema ya mencionado: Granada (1635), de Agustín Collado del Hierro ${ }^{6}$.

Las imágenes de Granada proliferan más todavía. En el Siglo de Oro, también es la "ciudad coronada", que desarrollará, entre otros, Calderón de la Barca en La Niña de Gómez Arias. Con este rasgo se

\footnotetext{
${ }^{6}$ Por falta de espacio no se le presta más atención a esta extensa obra -compuesta por doce libros-, que merecería ella sola un estudio completo en el que entrarían todas las imágenes de la ciudad. No obstante, este poema no fue publicado en su época por lo que la recepción generalizada de la misma no se iniciará hasta finales del siglo XIX. Véase la edición de Carmen C. López Carmona (Collado del Hierro 2005).
} 
alude a su naturaleza amurallada, salpicada con grandes torres. Pero Calderón da un paso más:
Bellísima Granada, ciudad de tantos rayos coronada cuantas tus torres bellas saben participar de las estrellas, y a cuyos riscos liberal se atreve tu sierra altiva a convertir en nieve, cuando eminente sube a ser cielo, cansada de ser nube; cada vez que te miro grande te aclamo, si imperial te admiro. (apud Orozco 2000: 70)

La ciudad está aquí, debido a su altura, coronada por el sol y por las estrellas ${ }^{7}$. $Y$, de nuevo, el espacio urbano entra en comunicación con la naturaleza, en este caso con la sierra que asciende hasta el cielo. Abandonemos ahora unos minutos la poesía para ir a la prosa de Cervantes. Una vez que la imagen de Granada como ciudad ideal se ha convertido en tópico literario, comienzan las imágenes negativas, que se prolongarán también a los siglos XIX y XX. Afirma Berganza en El coloquio de los perros:

iOh, cuántas y cuáles cosas te pudiera decir, Cipión amigo, desta morisca canalla, si no temiera no poderlas dar fin en dos semanas! Por maravilla se hallará entre tantos uno que crea derechamente en la sagrada ley cristiana; todo su intento es acuñar y guardar dinero acuñado, y para conseguirle trabajan y no comen; en entrando real en su poder, como no sea sencillo, le condenan a cárcel perpetua y a escuridad eterna; de modo que ganando siempre y gastando nunca, llegan y amontonan la mayor cantidad de dinero que hay en España [...]. (Cervantes apud Salvador 1996: 207)

En este caso, Granada es la ciudad de la avaricia, del morisco que acumula el capital sin hacer ni inversión ni mejora del país. Destaca aquí la modernidad de Cervantes, que huye de la imagen paradisíaca para ofrecer una más materialista -alejada de la visión idealizante- que Ilegará a Baroja y Ganivet.

${ }^{7}$ La ciudad cósmica, en contacto con las esferas celestes, ya se encuentra en Ibn Zamrak (1333-1393): "Sin par, radiante cúpula hay en ella / con encantos patentes y escondidos. / Su mano tiende a Orión por saludarla; / la luna a conversar con ella viene [...]" (apud Salvador 1996: 70). A ello alude también el romance de Góngora en la mención a Atlante (v. 20). 


\section{Algunas continuaciones en los siglos XIX y XX a las imágenes de Granada}

Este trabajo comenzaba advirtiendo sobre las tres concepciones de Granada: la ideal, la casticista y la negativa o crítico-trágica. La primera procede desde los primeros discursos descriptivos de la ciudad, desde la literatura árabe, y florece en el Siglo de Oro, como se ha visto. La segunda será cultivada sobre todo por los costumbristas románticos, donde el tiempo queda totalmente eliminado en la descripción de espacios y la defensa de su carácter españolista. Ejemplos de esta segunda imagen aparecen en Estébanez Calderón o Juan Valera. Por último, existe también una tercera imagen crítica, que se ha visto en Cervantes y que llegará a autores posteriores. Pero sobre todo predomina en los siglos XIX y XX la imagen de la ciudad como espacio ideal, metáfora de lo puro e incontaminado, que se opone a la realidad moderna e industrial (García Montero 1994: 101). Huyendo de su cotidianeidad surge el ideal de la Granada romántica, en deuda con los testimonios de autores extranjeros que habían visitado la ciudad, principalmente Chateaubriand, Washington Irving, Victor Hugo, Alexandre Dumas y Téophile Gautier. Entre los autores españoles, se ocupan de la ciudad el Duque de Rivas y José Zorrilla, cuyo estilo será recogido en el Modernismo por Francisco Villaespesa.

Este autor muestra también la obsesión por la Alhambra, que procedía de los viajeros románticos, hasta el punto de crearse un subgénero propio, el "Alhambrismo" (Varo Zafra 2000). Se ofrece así una imagen de Granada exótica, profundamente irreal, atemporal, legendaria, que buscaba en el pasado unos orígenes de nobleza que no existían en el presente de los poetas (Litvak 1985: 35). La Antología de Gerardo Diego (2007: 559-560) popularizó una imagen decadentista de Villaespesa, del Jardín de Lindaraja en ruinas, donde se ve una fuente que "solloza". Aquí, el pasado glorioso árabe es inalcanzable, al sujeto no le quedan fuerzas para salir de su hastío y prefiere "soñar eternamente que nunca ha existido". La visión pesimista de la ciudad pasará a Ganivet, en obras como Granada la bella (1896), cuya innovación será eliminar todos los tópicos para quedarse en la necesidad de "comprender" y "restaurar" la ciudad. La visión negativa se completará con otros autores como Pío Baroja (Villa-Real 1990: 22). En el siglo XX la imagen de Granada se seguirá renovando, sobre todo en la obra de Juan Ramón Jiménez, que dedicó un libro entero a la ciudad, Olvidos de Granada -escrito entre 1924 y 1928. La Generación del 27 también elaborará sus imágenes de Granada, mezclando la tradición con la vanguardia. Pero sobre todo, será Lorca quien más se ocupe de la ciudad, ya desde Impresiones y paisajes (1918). Estas son algunas aportaciones al discurso poético de Granada, cuyas imágenes prosiguen en la actualidad. 


\section{Conclusión}

Este itinerario por el discurso de la ciudad ha dejado una amplia galería de imágenes. Por un lado, la ciudad ideal, paraíso terrenal que surge al tiempo que se construye la Alhambra, con una literatura que se escribe sobre ella. Así, se crea una ciudad-paraíso que la literatura posterior seguirá cultivando como extensión de los primeros testimonios y como respuesta a la realidad industrial del siglo XIX. EI Siglo de Oro muestra un gran desarrollo y "topificación" de la Granada ideal y paradisíaca. De esa ciudad-jardín se exaltan sus elementos arquitectónicos, naturales y su población, a la vez que se manifiesta el miedo al paso del tiempo que va destruyendo esas bellezas. Se ha pasado del inventario de elogios que ofrecía Agustín de Rojas a la sensualidad de la ciudad "integral" de Góngora para llegar finalmente a la ciudad cósmica de Calderón, coronada de estrellas. Se ha entrado también en este trabajo a la poética del jardín privado, al carmen de Pedro Soto de Rojas, en donde encontramos otra solución a la lucha contra el tiempo. En el Paraíso cerrado para muchos no sólo se querrá llevar el paraíso al poema. Se tratará más bien de recrear de forma simbólica, como trasunto directo del paraíso divino, para así acercarse a la Verdad. Esta es la imagen ideal de la ciudad, que alterna con la negativa y la casticista. Pero por encima de todas las diferencias se erige una ciudad literaria para ser admirada y disfrutada y que el utilitarismo del urbanismo moderno ha intentado romper. Una ciudad cuyas aguas, como diría Lorca en su homenaje a Soto de Rojas, sirven sobre todo no para beberlas sino para escucharlas. 


\section{Bibliografía}

BARTHES, Roland (2009): "Semiología y urbanismo", en La aventura semiológica, pp. 337-350. Barcelona: Paidós.

COLLADO DEL HIERRO, Agustín (2005): Granada. Edición de Carmen C. López Carmona. Jaén: Universidad de Jaén.

DIEGO, Gerardo (2007): Poesía española. Antologías. Edición de José Teruel. Madrid: Cátedra.

EGIDO, Aurora (1981): "Introducción", en Pedro Soto de Rojas, Paraíso cerrado para muchos, jardines abiertos para pocos, pp. 11-63. Madrid: Cátedra.

FRATICELLI, Barbara (2006): "La imagen literaria de la ciudad", en Eugenia Popeanga (coord.), La ciudad como escritura, pp. 5-15. Bucarest: Cartea Universitara.

GARCÍA MONTERO, Luis (1994): "Andalucía como imagen literaria", en José María Enguita y José-Carlos Mainer (eds.), Literaturas regionales en España, pp. 101-115. Zaragoza: Institución Fernando el Católico.

GÓNGORA, Luis de (1992): Sonetos completos. Edición de Biruté Ciplijauskaité. Madrid: Castalia.

- (1998): Romances, vol. I. Edición de Antonio Carreira. Barcelona: Quaderns Crema.

- (2000): Romances. Edición de Antonio Carreño. Madrid: Cátedra.

LITVAK, Lily (1985): El jardín de Aláh. Temas del exotismo musulmán en España (1880-1913). Granada: Don Quijote.

MONTERO VALLEJO, Manuel (1996): Historia del urbanismo en España, vol. I: Del Eneolítico a la Baja Edad Media. Madrid: Cátedra.

OROZCO DÍAZ, Emilio (2000): Granada en la poesía barroca. Granada: Universidad de Granada.

ROJAS, Agustín de (1972): El viaje entretenido. Edición de Jean-Pierre Ressot. Madrid: Castalia.

SALVADOR, Álvaro (1996): Guía literaria de la ciudad de Granada, vol. I: Itinerarios árabe y renacentista. Granada: Comares.

SOTO DE ROJAS, Pedro (1981): Paraíso cerrado para muchos, jardines abiertos para pocos. Edición de Aurora Egido. Madrid: Cátedra.

VARO ZAFRA, Juan (2000): "Sueño oriental al cubo vanguardista: la Alhambra de García Lorca", en Andrés Soria Olmedo et al. (coords.), Federico García Lorca, clásico moderno (1898-1998). Granada: Diputación de Granada.

VILLA-REAL, Ricardo (1990): Homenaje a Granada. Selección de textos poéticos y literarios. Granada: Miguel Sánchez. 